\title{
PENDEKATAN KOMUNIKASI PEER GROUP DALAM INTERAKSI REMAJA PADA PROGRAM KAMPUNG KELUARGA BERENCANA BARUKUPA
}

\author{
Astri Dwi Andriani, Destiana Husnul Chotimah \\ Program Studi Ilmu Komunikasi, Universitas Putra Indonesia Cianjur \\ Jalan Dr. Muwardi No. 66 By-Pass, Kec. Cianjur, Kabupaten Cianjur \\ No. HP: 081572341342; 085624421816 \\ e-mail: astridwiandriyani@unpi-cianjur.mail.com,viedestiana@unpi-cianjur.mail.com
}

Naskah diterima tanggal 21 Oktober 2020 direvisi tanggal 24 Maret 2021 disetujui tanggal 1 April 2021

\begin{abstract}
Abstrak
Penelitian ini adalah penelitian kualitatif untuk meneliti program pemerintah yaitu Program Kampung KB khususnya Pusat Informasi Konseling Remaja (PIK R). Tujuan penelitian ini untuk menjelaskan pendekatan komunikasi Peer group dalam Interaksi Remaja pada Program Kampung KB di RW 03 Desa Sukatani Kecamatan Pacet. Penelitian ini menggunakan pendekatan kualitatif dengan metode studi kasus. Data yang di analisis adalah hasil wawancara dengan ketua kampung KB, ketua PIK R dan pembina PIK R, pengamat langsung di RW 03 Desa Sukatani dan kegiatan remaja. Serta telaah dokumen di kantor DPPKBP3A dan pengecekan atau pembanding data tokoh pemuda, penanggungjawab kegiatan dan tokoh masyarakat. Diharapkan melalui penelitian ini dapat melahirkan suatu model pendekatan komunikasi peer group dalam komunitas remaja yang dapat diterapkan untuk meningkatkan pencapaian keberhasilan Program Kampung di wilayah lainnya di Indonesia. Adapun hasil dari penelitian ini adalah pendekatan pola komunikasi peer group dalam program Kampung KB di RW 03 Desa Sukatani Kecamatan Pacet cukup signifikan memberikan dampak yang progresif terhadap penguatan pengetahuan remaja mengenai kesehatan reproduksi, resiko aktivitas seks pra nikah, dan pernikahan dini. Pendekatan komunikasi peer group cukup efektif dalam menularkan pengetahuan tersebut kepada remaja lainnya yang berada di luar RW 03 Desa Sukatani Kecamatan Pacet. Namun pengetahuan ini relatif tidak memberikan perubahan yang signifikan terhadap sikap dan perilaku remaja dalam pergaulan seks bebas dan penurunan tingkat pernikahan dini karena adanya faktor lain yang mempengaruhi diantaranya mudahnya remaja mengakses tayangan pornografi dan pornoaksi melalui media sosial, serta kebutuhan ekonomi keluarga yang memilih remaja untuk menikah di usia dini.
\end{abstract}

Kata-kata kunci: Interaksi; peer group; pendekatan komunikasi; program kampung KB; remaja.

\begin{abstract}
This research is a qualitative research to examine government programs, namely the $K B$ Village Program, especially the Youth Counseling Information Center (PIK R). The purpose of this study was to find out how the Peer group communication approach in Youth Interaction in the KB Village Program in RW 03 Sukatani Village, Pacet District. This research uses a qualitative approach with a case study method. The data analyzed were the results of interviews with the head of the KB village, the head of PIK $R$ and the coach of PIK $R$, direct observers at $R W 03$ Sukatani Village and youth activities. As well as reviewing documents at the DPPKBP3A office and checking or comparing data on youth leaders, people in charge of activities and community leaders. It is hoped that this research can produce a peer group
\end{abstract}


Jurnal Komunikasi Universitas Garut: Hasil Pemikiran dan Penelitian

Vol. 7, No. 1, April 2021

Halaman 591-605

communication approach model in the youth community that can be applied to increase the achievement of the success of the Kampung Program in other regions in Indonesia. The results of this study are the peer group communication pattern approach in the KB Kampung program in RW 03 Sukatani Village, Pacet District, which has a significant progressive impact on strengthening adolescent knowledge about reproductive health, the risks of premarital sexual activity, and early marriage. The peer group communication approach is quite effective in transmitting this knowledge to other adolescents who are outside RW 03 Sukatani Village, Pacet District. However, this knowledge relatively does not provide a significant change in the attitudes and behavior of adolescents in promiscuity and a decrease in the rate of early marriage due to other factors that influence, including the ease with which teenagers access pornography and porn action through social media, as well as the economic needs of families who choose teenagers to marry. at an early age.

Keyword: Interaction; peer group; communication approach; family planning village program; adolescents

\section{Pendahuluan}

Remaja merupakan tunas bangsa yang akan menentukan masa depan sebuah negara. Jumlahnya cukup besar, di Kabupaten Cianjur diketahui remaja berumur 10 tahun - 24 tahun berjumlah 603.541 atau $26.89 \%$ dari jumlah penduduk. Melihat jumlahnya yang sangat besar, maka remaja menjadi generasi penerus bangsa perlu dipersiapkan menjadi manusia yang sehat secara jasmani, rohani, mental, dan spiritual (Direktorat Bina Ketahanan Remaja, 2014).

Meski demikian, faktanya, berbagai penelitian menunjukkan bahwa remaja mempunyai permasalahan yang sangat komplek seiring dengan masa transisi yang dialaminya. Penelitian yang dilakukan oleh BKKBN menunjukan bahwa terdapat peningkatan perlakuan seksual yang dialami oleh remaja usia 15 hingga 24 tahun, baik perempuan maupun laki-laki. Dari data tersebut, diketahui bahwa sebanyak $6 \%$ remaja laki-laki mengaku pernah melakukan hubungan seksual pra nikah. Sementara itu, sebanyak $1 \%$ perempuan mengaku pernah melakukan hal yang sama. Hal ini dipicu oleh perilaku pengalaman pacaran yang dilakukan oleh remaja di Indonesia. BKKBN pada tahun 2015 merilis bahwa pengalaman pacaran remaja kini semakin terbuka dan berani. Hal ini terlihat dari sikap berpegangan tangan, perempuan sebanyak 68,3\% sedangkan laki-laki sebanyak $69 \%$. Tidak hanya berpegangan tangan, perilaku lain seperti ciuman juga dilakukan oleh remaha, dengan persentasi perempuan sebanyak 29,3\% dan laki-laki sebanyak 41,2\%. Yang terakhir adalah perilaku merangsang atau meraba, remaja perempuan mengaku melakukan kegiatan tersebut dalam pacara dengan jumlah persentasi sebanyak $9,1 \%$ sedangkan lakilaki sebanyak 26,5\% (BKKBN, 2014).

Hal ini tidak diimbangi oleh kesadaran remaja dalam literasi masalah kesehatan prerpoduksi. Hasil Survei demografi kesehatan Indonesia diketahui bahwa pada tahun 2007 kesadaran remaja mengenai kesehatan reproduksi relatif rendah. Jumlah remaja perempuan yang tidak tahu tentang perubahan fisik yang dialaminya mencapai persentase $13,3 \%$. Selain itu, median usia kawin pertama relatif rendah yaitu 19,8 tahun (UMY, 2016). Sementara itu, dari sisi Napza, berdasarkan data Badan Narkotika 
Jurnal Komunikasi Universitas Garut: Hasil Pemikiran dan Penelitian

Vol. 7, No. 1, April 2021

Halaman 591-605

Nasional Tahun 2008, menunjukkan jumlah pemakai Napza adalah 115.404 orang. Dari total pengguna Napza tersebut, 51.986 orang adalah remaja yang berumur 16 hingga 24 tahun (BKKBN, 2014).

Tingginya angka tersebut membuat pemerintah pusat melalui $\mathrm{BKKBN}$ menggulirkan program nasional berupa Program Kampung Keluarga Berencana (KB) pada 14 Januari 2016. Salah satu sasaran utama Kampung KB adalah pembinaan remaja yang disebut kelompok Pusat Informasi Kegiatan Remaja (PIK R) yang di dalamnya terdapat berbagai macam program untuk memberikan layanan konseling dan informasi mengenai 8 fungsi keluarga, kesehatan reproduksi, pendewasaan usia perkawinan, bahaya seks bebas, Napza, HIV dan AIDS, serta menerangkan masalah keterampilan hidup, gender, advokasi dan KIE (BKKBN, 2014).

Masyarakat RW 03 Des.Sukatani, Kec.Pacet, Kab.Cianjur adalah salah satu yang melaksanakan PIK R, dan menjadi program percontohan di Kabupaten Cianjur. Melihat fenomena ini, peneliti tertarik untuk menganalisis bagaimana peran serta remaja dalam program Kampung KB melalui pendekatan metode peer group. Peneliti mengambil sampel penelitian di Desa Sukatani RW 03 yang menjadi Kampung KB setingkat RW dengan judul Pendekatan Komunikasi Peer group dalam Interaksi Remaja pada Program Kampung KB di RW 03 Desa Sukatani Kecamatan Pacet.

Adapun tujuan dari penelitian ini adalah untuk mengetahui model pendekatan komunikasi Peer group dalam interaksi remaja pada Program Kampung KB di RW 03 Desa Sukatani Kecamatan Pacet.

Berdasarkan data yang dihimpun dari WHO dan UNFPA, remaja adalah orang muda (youth people) yaitu penduduk atau masyarakat yang berusia antara 10 hingga 24 tahun yang belum menikah. Adapun pengertian dari Keluarga Berencana (KB) program yang dibuat untuk mencapai keluarga berkualitas dengan cara mengatur usia ideal melahirkan, mengatur kehamilan, mengatur kelahiran anak, dan jarak kelahiran anak (BKKBN, 2014).

Kampung Keluarga Berencana (KB)

Kampung KB ialah satuan setingkat Dusun, Rukun Warga, atau yang setara dengannya yang memiliki kriteria khusus memiliki perencanaan dan pelaksanaan dalam tata kehidupan dalam membangun kebersamaan dengan cara silih asah, silih asih, dan silih asuh dalam bingkai program Kependudukan Keluarga Berencana dan Pembangunan Keluarga (KKBPK). Program ini dibuat secara sistematis dan terintegrasi dengan sektor lain, yang bertujuan untuk mengoptimalkan fungsi keluarga demi mewujudkan keluarga sejahtera dan terbebas dari kemiskinan, keterbelakangan dan kebodohan. KKBPK adalah program yang sangat strategis dalam konteks pembangunan nasioanal. Program KB tidak hanya ditempatkan sebagai program untuk pengendalian penduduk, melainkan untuk pembangunan dan pemberdayaan keluarga. Jumlah penduduk yang besar bila tidak disertai dengan kualitas, maka hanya akan menjadi beban bagi pembangunan. Namun sebaliknya, jumlah penduduk yang terkendali dengan kualitas yang unggul akan menjadikan negara kita sebagai negara yang unggul dan berdaya saing (BKKBN, 2018).

Tujuan kampung KB adalah 
Jurnal Komunikasi Universitas Garut: Hasil Pemikiran dan Penelitian

Vol. 7, No. 1, April 2021

Halaman 591-605

meningkatkan kualitas hidup keluarga dan masyarakat melalui program KKBPK yang terintegrasi dengan sektor pembangunan lain. Adapun sasaran kampung KB. Sasaran langsung; keluarga, Pasangan Usia Subur, masyarakat, balita, remaja dan lansia. Sasaran tidak langsung; tokohtokoh masyarakat, organisasi masyarakat (Pos KB, sub-pos KB, DKM, Karang Taruna dsb), petugas lapangan dan mitra kerja (BKKBN, 2018).

Generasi Berencana (GenRe) ialah mahasiswa/remaja yang mempunyai pengetahuan, perilaku, dan sikap sebagai mahasiswa atau remaja yang mampu mengenyam pendidikan secara terencana, berkarir secara terencana, dan menikah secara terencana pula sesuai berdasarkan siklus kesehatan reproduksi. Hal ini diupayakan dalam rangka menyiapkan kehidupan keluarga yang ideal.

PIK R/M merupakan singkatan dari

Pusat Informasi Konseling
Remaja/Mahasiswa. PIK R/M adalah wadah kegiatan program GenRe dalam menyiapkan kehidupan berkeluarga bagi remaja yang dikeloka sendiri oleh remaja, dilakukan oleh remaja, dan ditujukan untuk memberikan layanan informasi dan konseling mengenai perencanaan hidup berkeluarga untuk remaja serta kegiatan penunjang lainnya (BKKBN, 2014).

Aktivitas ini dikelola oleh para remaja atau mahasiswa yang berumur maksimal 24 tahun, memiliki komitmen dalam pengelolaan PIK R/M, dan belum menikah. Sama seperti organisasi lain, PIK R/M memiliki ketua, sekertaris, bendahara, bidang program, bidang administrasi, dan kegiatan lain yang sesuai kebutuhan (Direktorat Bina Ketahanan Remaja, 2014).

Adapun strategi Pengelolaan PIK
Remaja antara lain: Melakukan advokasi tentang pertumbuhan dan pengembangan PIK R/M

a. Melakukan promosi dan sosialisasi tentang PIK R/M

b. Menyediakan dukungan angaran bagi kegiatan PIKR/M, baik dari dana APBN, APBD, maupun dari sumber dana lainnya

c. Mengembangkan Pusat Informasi Konseling Remaja

d. Melaksanakan pelatihan, orientasi, magang dan studi banding bagi SDM pengelola PIK R/M

e. Melakukan pengadaan sarana dan prasarana pendukung Pusat Informasi Konseling Remaja

f. Mengembangkan materi subtansi PIK $\mathrm{R} / \mathrm{M}$ sesuai dengan dinamika remaja/mahsiswa

g. Mengembangkan kegiatan yang menarik minat remaja/mahasiswa

h. Melakukan monitoring dan evaluasi, serta melaksanakan pembinaan secara berjenjang.

Interaksi komunikasi kelompok Peer group atau teman sebaya adalah komunikasi yang dilakukan secara dua arah dalam kelompok yang anggotanya berada dalam satu tingkatan atau range usia yang sama. Komunikasi kelompok teman sebaya akan berjalan baik jika interaksi yang dilakukan cukup intens atau sering. Interaksi komunikasi mampu memengaruhi perilaku remaja dilihat dari isi pesan, durasi, dan frekuensi dalam setiap interaksi yang dilakukan.

Menurut sebuah riset, mengemukakan bahwa seseorang dengan usia dan tingkat kedewasaan yang sama bisa berfungsi sebagai sumber utama informasi dan perbandingan tentang dunia luar selain keluarga (Santrock, 2007). Hal 
Jurnal Komunikasi Universitas Garut: Hasil Pemikiran dan Penelitian

Vol. 7, No. 1, April 2021

Halaman 591-605

ini dikuatkan oleh studi yang mengemumukan bahwa pada saat seseorang berusia menginjak remaja, maka umumnya dia akan bergabung dengan kelompok teman sebaya. Remaja, menurut Hurlock memiliki kecenderungan untuk membentuk komunitas atau kelompok dan melakukan interaksi bersama temantemannya. Hal ini dilakukan untuk melepaskan diri dari ketergantungan kepada orang tua atau keluarga (Hurlock, 2009).

\section{Metode Penelitian}

Jenis yang peneliti gunakan adalah kualitatif. Penelitian kualitatif adalah penelitian yang bermaksud untuk memahami fenomena tentang apa yang dialami oleh subjek penelitian, misalnya perilaku, persepsi,motivasi, tindakan, dan lain-lain, secara holistik dan dengan cara deskripsi dalam bentuk kata-kata dan bahasa, pada suatu konteks khusus yang alamiah (Moleong, 2006). Alasan yang mendasari dipergunakannya pendekatan kualitatif ini adalah masalah yang dikaji mengenai peran remaja pada program pemerintah kampung KB (keluarga berencana) melalui pendekatan peer group. Selain itu karena objek yang diteliti adalah suatu bentuk realita yang abstrak, di mana indikatornya hanya dapat diketahui melalui sikap moralitas, tindakan atau perilaku, dan ucapan. Dengan begitu, maka pendekatan kualitatif ini mampu memberikan pemaparan yang luas, jelas, serta mendalam.

Sementara itu, metode yang digunakan peneliti adalah metode studi kasus.

"Studi kasus adalah uraian dan penjelasan komprehensif mengenai

berbagai aspek seorang individu, suatu kelompok, suatu organisasi (komunitas), suatu program, atau situasi sosial. Peneliti studi kasus menelaah sebanyak mungkin data mengenai subjek yang diteliti. Mereka sering menggunakan berbagai metode: wawancara (riwayat hidup), pengamatan, penelaahan dokumen, (hasil) survei, dan data apapun untuk menguraikan suatu kasus secara terinci (Mulyana, 2011)."

Melalui pendekatan studi kasus, peneliti bermaksud menggali informasi bagaimana peran serta remaja dalam menyebarluaskan pesan-pesan program Kampung $\mathrm{KB}$ dan bagaimana remaja mengkonstruksi sebuah komunitas Kampung KB melalui metode peer group.

Jenis data kualitatif didalam penelitian ini meliputi : sejarah singkat Kampung KB dan program PIK R, letak geografis objek, stuktur organisasi, visi dan misi, program Kampung KB, kegiatan program kampung $\mathrm{KB}$ dan tingkat partisipasi remaja dalam program kampung KB. Sementara itu, ada dua jenis sumber data penelitian, yakni data primer dan data sekunder. Sementara itu yang menjadi sumber data penelitian berasal dari sumber data primer seperti pengamatan dan wawancara, serta berasal dari sumber data sekunder analisis dokumen, dokumen, arsip, catatan, dan gambar lain yang berkaitan dengan penelitian (Simabur, 2014). Sumber Data: a) Data Primer: Wawancara dengan pengurus kampung $\mathrm{KB}$, Institusi pemerintah yang bertanggugjawab dan pembina kampung KB dan remaja; dan b) Data Sekunder: Bahan pustaka, literatur, penelitian terdahulu, buku, laporan-laporan kegiatan 
Jurnal Komunikasi Universitas Garut: Hasil Pemikiran dan Penelitian

Vol. 7, No. 1, April 2021

Halaman 591-605

yang diadakan oleh pengelola Kampung KB.

Sementara itu, subjek penelitian atau informan (narasumber) penelitian adalah seseorang yang memiliki informasi (data) banyak mengenai objek yang sedang diteliti, dimintai informasi mengenai objek yang sedang diteliti. Informan (narasumber) penelitian adalah orang yang diwawancarai, dimintai informasi data ataupun fakta dari suatu objek penelitian (Bungin, 2003). Dalam melakukan penelitian, (pengumpulan data) peneliti dapat bergerak dari satu informasi ke informasi lainnya sesuai kebutuhan.

Tabel 1

Profil Informan Penelitian

\begin{tabular}{|c|c|c|c|c|}
\hline No. & Nama & Alamat & Posisi & Profil \\
\hline 1. & Ahmad Sobana & $\begin{array}{l}\text { Kp. Barukupa } \\
\text { 2/3 Sukatani. } \\
\text { Pacet-Cianjur }\end{array}$ & $\begin{array}{l}\text { Ketua Kampung } \\
\text { KB \& Ketua RW } \\
03\end{array}$ & $\begin{array}{l}\text { Terlahir pada tanggal } 17 \text { Agustus } 1960 \text { atau } \\
\text { kini berusia } 59 \text { tahun merupakan ayah dari } 4 \\
\text { orang putra dan } 2 \text { putri, aktifitas keseharian } \\
\text { selain menjadi ketua RW berwiraswasta dan } \\
\text { bertani. }\end{array}$ \\
\hline 2. & Yusup & $\begin{array}{l}\text { Kp. Brukupa } \\
4 / 3 \quad \text { Ds } \\
\text { Sukatani. } \\
\text { Pacet-Cianjur }\end{array}$ & $\begin{array}{l}\text { ketua RT } 04 \text { RW } \\
03\end{array}$ & $\begin{array}{l}\text { Yusup sebagai ketua RT yang menjabat } \\
\text { selama } 2 \text { periode terlahir pada tanggal } 05 \text { Juni } \\
1971 \text { merupakan ayah } 2 \text { orang putra dan } 1 \\
\text { putri, berperan aktif dalam kegiatan remaja } \\
\text { bahkan sebagai koordinator kegiatan remaja } \\
\text { dalam pengolahan sampah. Aktifitas } \\
\text { keseharian selain menjadi ketua RT } 04 \mathrm{RW} \\
03 \text { adalah petani }\end{array}$ \\
\hline 3. & $\begin{array}{l}\text { Nita } \\
\text { Nurbayuningsih }\end{array}$ & $\begin{array}{l}\text { Kp } \text { Barukupa } \\
2 / 3 \quad \text { Ds } \\
\text { Sukatani. } \\
\text { Pacet-Cianjur }\end{array}$ & $\begin{array}{l}\text { Ketua } \quad \text { PIK } \\
\text { Remaja }\end{array}$ & $\begin{array}{l}\text { Merupakan anak kedua dari tiga bersaudara } \\
\text { dari pasangan Uud Sopandi dan Ayi, yang } \\
\text { lahir pada tanggal } 19 \text { februari } 1997 \text {. Aktifitas } \\
\text { saat ini menjadi mahasiswa di Universitas } \\
\text { Islam Nusantara PG PAUD program S1 di } \\
\text { Bandung. }\end{array}$ \\
\hline 4. & $\begin{array}{l}\text { Ujang Nurul } \\
\text { Huda }\end{array}$ & $\begin{array}{l}\text { Kp. Brukupa } \\
3 / 3 \quad \text { Ds. } \\
\text { Sukatani. } \\
\text { Pacet-Cianjur }\end{array}$ & $\begin{array}{l}\text { Tokoh } \\
\text { pemuda/pendidik } \\
\text { sebaya }\end{array}$ & $\begin{array}{l}\text { Merupakan salah satu staff pengajar SMP IT } \\
\text { Miftahussa'adah Al-Islamiyah di Barukupa } \\
\text { Kecamatan Pacet. Pendidikan terakhir yang } \\
\text { ditempuh Paket C berkeinginan kuat dengan } \\
\text { ikut pelatihan bahasa Inggris di Kampung } \\
\text { Pare dengan biaya dari pihak Pesantren dan } \\
\text { dikembangkan kembali di lingkungan } \\
\text { pesantren. }\end{array}$ \\
\hline 5. & Santi & $\begin{array}{l}\text { Kp. Barukupa } \\
2 / 3 \quad \text { Ds. } \\
\text { Sukatani. } \\
\text { Pacet-Cianjur }\end{array}$ & \begin{tabular}{lr}
\multicolumn{2}{l}{ Penanggungjawab } \\
kegiatan & PIK \\
Remaja &
\end{tabular} & $\begin{array}{l}\text { Merupakan salah satu staff DPPKBP3A yang } \\
\text { merupakan Petugas Lapangan Posyandu dan } \\
\text { merupakan warga asli Kampung Barukupa } \\
\text { RW 03. Pendidikan terakhir SLTA dan aktif } \\
\text { menjadi staff pengajar di Taman Pendidikan } \\
\text { Al-quran Darul Falah di Barukupa. }\end{array}$ \\
\hline 6. & $\begin{array}{l}\text { Wawan } \\
\text { Ridwan, S.Ip }\end{array}$ & $\begin{array}{l}\text { Jl. Wijaya } \\
\text { Kusumah Rt } \\
04 / 05 \quad \text { Ds. } \\
\text { Cipendawa. } \\
\text { Pacet-Cianjur }\end{array}$ & $\begin{array}{lr}\text { Pembina } & \text { Kp. } \\
\text { KUBA Tingkat } \\
\text { Kecamatan }\end{array}$ & $\begin{array}{l}\text { Perwakilan Institusi } \text { Pemerintah yakni } \\
\text { sebagai Kepala Pusbin PPKBP3A Kec. Pacet }\end{array}$ \\
\hline 7. & $\begin{array}{l}\text { H. Udin Sanusi } \\
\text { Yandi, S.Pd }\end{array}$ & $\begin{array}{l}\text { Kp. Kayu } \\
\text { manis 2/8 Ds. } \\
\text { Sukatani. } \\
\text { Pacet-Cianjur }\end{array}$ & $\begin{array}{l}\text { Pembina Kp. KB } \\
\text { Tingkat Desa }\end{array}$ & $\begin{array}{l}\text { Kepala Desa Sukatani Kecamatan Pacet } \\
\text { Kabupaten Cianjur. }\end{array}$ \\
\hline
\end{tabular}

Sumber: Olahan Peneliti, 2020. 
Jurnal Komunikasi Universitas Garut: Hasil Pemikiran dan Penelitian

Vol. 7, No. 1, April 2021

Halaman 591-605

Pengumpulan data merupakan langkah yang sangat penting dalam penelitian, karena itu peneliti akan coba memaksimalkan potensi yang dimiliki peneliti untuk mengumpulkan data sebaik dan sevalid mungkin. Prosedur, standar, sistematika dan teknik-teknik dalam mengumpulkan data menjadi hal penting yang harus peneliti kuasai, sehigga data yang dihasilkan dapat sesuai dengan kebutuhan penelitian ini.

Teknik pengumpulan data yang dilakukan oleh tim peneliti adalah dengan cara melakukan observasi langsung. Observasi atau pengamatan langsung merupakan kegiatan yang setiap saat dilakukan dengan kelengkapan pancaindera yang dimiliki (Ardianto, 2011). Inti dari kegiatan observasi lapangan adalah untuk memahami lingkungan yang hendak diteliti, sehingga kegiatan ini perlu dilakukan setiap saat dengan segenap pancaindera yang dimiliki seperti melihat atau mengamati, mendengar, mengobrol dengan orang lain. Dalam rangka mendukung penelitian ini, peneliti menggunakan alat/instrumen kamera. Peneliti berpartisipasi dalam interaksi dengan unsur pengurus, remaja dan pembina kampung KB.

Selain observasi langsung, teknik pengumpulan data yang dilakukan adalah wawancara. Wawancara berarti komunikasi antara dua orang, melibatkan seseorang yang ingin memperoleh informasi dari seorang lainnya dengan mengajukan pertanyaan-pertanyaan berdasarkan tujuan tertentu (Mulyana, 2011). Dalam penelitian ini, wawancara digunakan untuk mengetahui persepsi responden dalam hal ini remaja RW 03 Desa Sukatani, Kecamatan Pacet yaitu tentang program Kampung KBAdapun wawancara dilakukan secara langsung, dialogis dengan responden, dan direkam serta diabadikan dengan kamera.

Kemudian, teknik pengumpulan data yang lainnya adalah kepustakaan dan dokumen. Dokumen merupakan catatan peritiswa yang sudah berlalu. Dokumen bisa berbentuk tulisan, gambar, atau karya - karya monumental dari seseorang. Studi dokumen merupakan pelengkap dari penggunaan metode observasi dan wawancara dalam penelitian kualitatif. Aktivitas dokumentasi yang dilakukan guna memperoleh bahan tertuli, seperti buku panduan kampung KB yang berkaitan dengan peran remaja di Kampung KB RW 03 Desa Sukatani, dan dokumen foto yang berkaitan dengan masalah penelitian (Arikunto, 2012).

\section{Hasil Penelitian dan Pembahasan}

Profil Kampung KB Barukupa adalah sebuah kampung/daerah yang terletak di Kp.Barukupa Desa Sukatani, Kecamatan Pacet Kabupaten Cianjur yang mana kampung tersebut ditunjuk sebagai kampung yang mengimplementasi program-program Keluarga Berencana (KB) secara lengkap dan terpadu. Kampung KB Barukupa dibentuk untuk kegiatan diklat Kampung KB yang dilaksanakan oleh Balai Diklat KB Bogor pada tanggal 08 April 2018. Pembentukkan Kampung KB diinisiasi oleh Dinas DPPKBP3A \& Balai Diklat KB Kota Bogor. Dalam program Kampung KB tersebut dilaksanakan pengimplementasian program KB seperti sosialisasi delapan fungsi keluarga, misalnya fungsi agama, fungsi pendidikan, fungsi reproduksi, fungsi ekonomi, fungsi perlindungan, fungsi kasih sayang, fungsi sosial budaya, dan fungsi lingkungan. Selain sosialisasi 
dan penerapan program 8 fungsi keluarga, di Kampung KB Barukupa juga dilaksanakan sosialisasi Program KKBPK (Kependudukan Keluarga Berencana dan Pembangunan) seperti misalnya pendewasaan usia pekawinan, pengaturan kelahiran, pemantapan ketahanan keluarga dan pemberdayaan ekonomi keluarga ditambah dengan pengendalian, pemantauan, pengamatan serta pembinaan penduduk merupakan bagian dari pengentasan kemiskinan. Selain itu dilaksanakan juga kunjungan lapangan ke posyandu dan rumah warga untuk melakukan KIE (Komunikasi Informasi Edukasi) secara individu maupun kelompok mengenai program Keluarga Berencana yaitu pemakaian alat kontrasepsi jangka panjang dan pelayanan kontrasepsi.

\section{Kegiatan PIK/Remaja di Kampung KB Barukupa}

Organisasi PIK Remaja yang dibentuk dalam rangka Kampung KB Barukupa merupakan organisasi bentukkan DPPKBP3A yang bertujuan menyampaikan program KKBPK yaitu mengenai Delapan Fungsi Keluarga bagi remaja dengan tujuan menjadikan remaja sebagai penerus bangsa memiliki wawasan yang luas mengenai fungsi keluarga, akan tetapi program PIK Remaja yang seharusnya di bawah pembinaan DPPKBP3A tidak berjalan dengan semestinya. Remaja memiliki kegiatankegiatan yang hampir mirip dengan program PIK Remaja berjalan tidak berdasarkan organisasi resmi PIK Remaja, kegiatan berjalan berdasarkan rasa ingin pengakuan keberadaan remaja oleh masyarakat serta adanya keterkaitan pihak pesantren yang peduli akan perkembangan pergaulan remaja sehingga sebagian remaja yang memiliki potensi diberikan pendidikan seperti salah satu remaja yang diberikan kesempatan untuk memperdalam bahasa Inggris di Kampung Pare dan selanjutnya mengembangkan hasil pendidikan di lingkungan pesantren dan di kalangan remaja. Remaja yang mengenyam pendidikan tinggi dilibatkan dalam kegiatan pengajaran seperti di Taman Pendidikan Al-quran. Remaja Barukupa sudah memiliki kegiatankegiatan baik dalam bidang olah raga dengan ditemukannya klub sepak bola dengan adanya fasilitas lapangan sepak bola remaja Barukupa hampir setiap tahun menyelanggarakan pertandingan sepak bola dengan mengundang klub-klub sepakbola yang berasal dari wilayah Desa sukatani.

Remaja Barukupa juga bekerjasama dengan pihak pesantren mengadakan pengajian rutin setiap hari kamis sore bertempat di Pesantren Miftahu Saa'dah remaja yang menjadi santri maupun bukan santri dapat berbaur bersama-sama, sehingga remaja yang berada diluar pesantren dapat dilibatkan menjadi pencari dana untuk kegiatan penghapal Al-quran bagi yatim. Untuk kegiatan penggalangan dana pihak pembina kampung KB tingkat Desa dan Kecamatan menjadi donatur tetap semenjak pembentukan kegiatan PIK R.

\section{Pendekatan Komunikasi Peer group dalam Interaksi Remaja pada Program Kampung KB di RW 03 Desa Sukatani Kecamatan Pacet}

Kuatnya pengaruh kelompok sebaya (peer group) dikarenakan remaja lebih banyak berada diluar rumah bersama dengan teman-teman sebaya sebagai kelompok, maka dapatlah dimengerti 
bahwa pengaruh teman-teman sebaya pada sikap, pembicaraan, minat, penampilan, dan perilaku lebih besar daripada pengaruh keluarga. Gambaran kelompok sebaya, pada dasarnya manusia memiliki dua hasrat utama yaitu keinginan untuk bersatu dengan masyarakat dan keinginan untuk bersatu dengan alam sekitarnya, oleh karena itu kemudian dibentuklah kelompok-kelompok sosial yang menempatkan individu bersama dengan orang-orang disekelilingnya untuk memenuhi keinginan tersebut. Kelompok teman sebaya sebagai lingkungan sosial bagi remaja (siswa) mempunyai peranan penting bagi perkembangan kepribadiannya, salah satunya untuk mengembangkan identitas diri serta mengembangkan kemampuan komunikasi interpersonal dalam pergaulan dengan kelompok teman sebaya. Memiliki beberapa persamaan adalah salah satu kriteria dalam pembentukan kelompok sebaya.

Kelompok sebaya yang berada di lingkungan Kampung KB Barukupa yang tergabung dalam PIK Remaja OpeRa merupakan teman sebaya yaitu sesama remaja dengan kisaran usia yang bergabung secara aktif adalah usia 18-24 tahun yang belum menikah, dimana sesama teman sebaya mereka lebih terbuka satu sama lain dan merasakan mereka suatu komunitas yang patut diakui keberadaannya. Satu sama lain saling mempengaruhi baik dalam sikap, penampilan dan kegiatan-kegiatan yang mereka lakukan. Dengan peer gropu atau teman sebaya dalam berbagai macam kegiatan mereka relatif kompak bahkan dalam hal hadir atau tidak hadir dalam suatu kegiatan. Untuk mengantisipasi pengaruh pergaulan yang tidak diinginkan remaja yang dianggap disenangi antar remaja yaitu kebetulan diangkat menjadi penanggungjawab kegiatan PIK Remaja membuat grup media sosial whatsapp namun keberadaan PIK Remaja belum yang dibentuk oleh Kampung KB tidak berpengaruh bahkan teman sebaya yang ditunjuk untuk menyampaikan programprogram PIK Remaja belum memahami betul tugas pokok teman sebaya. Teman sebaya hanya sebatas pada kegiatankegiatan di luar program Kampung KB. Pengaruh teman sebaya memberikan pengaruh yang cukup kuat dalam pembentukan karakter, pola pikir serta pengambilan keputusan remaja, karena teman sebaya merasa sama-sama memiliki kehidupan dan nasib yang sama terutama pada rentan usia remaja 10-15 tahun. Untuk mensiasati pengaruh teman sebaya ke pergaulan yang negatif salah satu tokoh pemuda yaitu Ujang Nurul Huda menjadi salah satu staff pengajar di MTS Miftahul Sa'adah sehingga memudahkan remaja tanggung untuk diarahkan dan remaja relatif lebih terbuka dengan guru di sekolah di bandingkan dengan orang tua di rumah.

\section{Bentuk Interaksi di Kampung KB Barukupa}

Interaksi terdiri dari berbagai kegiatan manusia yang berhubungan dengan kegiatan manusia lain. Adapun bentuk interaksi/komunikasi yang dilakukan remaja di Kampung KB Barukupa terdiri dari komunikasi interpersonal dan komunikasi kelompok.

\section{Komunikasi Antarpribadi (Interpesonal Commincation)}

Secara teoritis komunikasi antar pribadi diklasifikasikan menjdai dua jenis menurut sifatnya: 1) komunikasi diadik (dyadic communication) adalah 
Jurnal Komunikasi Universitas Garut: Hasil Pemikiran dan Penelitian

Vol. 7, No. 1, April 2021

Halaman 591-605

komunikasi antarpribadi yang berlangsung antara dua orang yakni seorang adalah komunikator yang menyampaikan pesan dan seorang lagi komunikan yang menerima pesan. Berdasarkan hasil wawancara dan observasi untuk komunikasi diadik antar remaja sering terjadi baik dalam meningkatkan pengembangan PIK Remaja bahkan antara remaja atau penangggungjawab kegiatan dengan pembina tingkat kecamatan sering dilakukan dalam rangka perencanaan kegiatan pembinaan, berdasarkan hasil wawancara mengenai pembinaan remaja dalam rangka meningkatkan dan mengembangkan PIK Remaja banyak terbentur oleh kesibukan antara remaja dan pembina sehingga sampai saat ini belum menemukan waktu yang tepat untuk merealisasikannya. 2) komunikasi triadik (triadic communication) adalah komunikasi antarpribadi yang pelakunya terdiri dari tiga orang, yakni seorang komunikator dan dua orang komunikan berdasarkan observasi komunikasi ini pernah terjadi pada saat perencanaan pembinaan yang menghadirkan pembina dari tingkat Kabupaten yaitu komunikasi antara pembina tingkat Kecamatan dengan penanggungjawab kegiatan PIK Remaja yaitu Santi dan ketua PIK Remaja yaitu Nita dimana yang menjadi komunikator adalah pembina PIK R tingkat Kecamatan Ani Kusdini, S.Sos komunikan Santi dan Nita. Untuk komunikasi antar remaja dalam komunikasi pribadi triadik sering dilakukan terutama dalam pembahasan kegiatan antar pengurus atau panitia kegiatan remaja.

\section{Komunikasi Kelompok}

Komunikasi kelompok (group communiction) berarti komunikasi yang berlangsung antara komunikator dengan kelompok orang yang jumlahnya lebih dari dua orang. Berdasarkan hasil observasi komunikasi kelompok dalam peran serta remaja dalam meningkatkan dan mengembangkan PIK Remaja sebagai konselor pernah terjadi pada saat pembinaan dengan pihak peserta diklat dari Balai Diklat KB Bogor dan pembina PIK Remaja Kabupaten, komunikasi antara konselor dan PIK Remaja jarang dilakukan dalam komunikasi kelompok.

\section{Kegiatan Rutin Remaja di Kampung KB Barukupa}

Sementara itu, kegiatan rutin yang dilakukan remaja Kampung KB Barukupa dalam rangka mengimplentasikan program KB diantaranya melalui FGD (Focus Group Discussion) dan kegiatan konseling, yang kemudian akan diuraikan sebagai berikut:

\section{Focus Group Discussion}

Persiapan dan desain rancangan FGD: 1) Tim FGD umumnya mencakup moderator, yaitu fasilitator diskusi yang terlatih dan memahami masalah yang dibahas. Hasil wawancara dengan nara sumber yang menjadi moderator adalah Santi yang merupakan salah satu staff DPPKBP3A setiap kegiatan diskusi ada moderator namun tidak bersifat formal bahkan tidak terstruktur, pencatat proses/notulen, yaitu orang bertugas mencatat inti permasalahan yang didiskusikan serta dinamika kelompoknya, umumnya dibantu dengan alat pencatatan untuk kegiatan pembinaan yang menjadi notulen adalah Nita, setiap kegiatan yang dianggap merupakan kegiatan yang relatif serius selalu ada pencatatan namun belum terstruktur secara sistematis. Penyedia logistik, yaitu orang-orang yang membantu kelancaran FGD berkaitan dengan 
Jurnal Komunikasi Universitas Garut: Hasil Pemikiran dan Penelitian

Vol. 7, No. 1, April 2021

Halaman 591-605

penyedia transportasi, konsumsi, alat dokumentasi. Untuk penyedia logistik kegiatan pembinaan remaja tidak hanya datang dari kalangan remaja tapi ada dukungan dari pihak keluarga terutama bagian konsumsi, sedangkan dokumentasi berhubung setiap remaja memiliki smart phone setiap kegiatan pembinaan tanpa ada instruksi dan penugasan khusus dokumentasi selalu ada, dan setiap dokumentasi kegiatan selalu di share atau dibagikan di media sosial masing-masing atau ke grup sosial media PIK Remaja; 2) memilih tempat dan mengatur tempat, pada prinsipnya FGD dapat dilakukan dimana saja, namun seyogianya tempat FGD yang dipilih hendaknya merupakan tempat yang netral, nyaman, aman, tidak bising dan lain sebagainya. Pada saat pembinaan dan pembentukan PIK Remaja tempat yang digunakan adalah Bale Sawala yang berada di ujung perkampungan jauh dari kebisingan bersifat netral dan nyaman. Namun untuk kegiatan yang berhubungan dengan kegiatan pesantren para remaja lebih sering mengadakan pertemuan di Pesantren atau di lokasi Taman Pendidikan Al-quran Darul Falah; 3) menyiapkan logistik adalah berbagai keperluan teknis yang diperlukan sebelum, selama, dan sesudah FGD terselenggara. Kebutuhan peserta FGD seperti transportasi, properti rehat, alat ibadah, konsumsi, insentif dan akomodasi (jika diperlukan). Pada saat pembentukkan PIK Remaja konsumsi diserahkan kepada penanggungjawab kegiatan dengan sumber dana dari dinas DPPKBP3A selaku penyelenggara kegiatan, tapi untuk insentif atau uang hadir tidak diberikan tapi ada daftar hadir dengan jumlah nominal yang ditanda tangani peserta berdasarkan keterangan penanggungjawab kegiatan PIK Remaja sebesar Rp. 75.000,- per orangnya; dan 4) menentukan jumlah peserta FGD, jumlah ideal adalah 7-11 orang, namun ada juga 47 orang, terlalu sedikit tidak memberikan variasi yang menarik dan terlalu banyak akan mengurangi kesempatan masingmasing peseta untuk memberikan sumbangan pikiran yang mendalam.

\section{Konseling}

Kegiatan konseling di Kampun KB Barukupa terjadi apabila ada permasalahan dalam kehidupan pribadi di kalangan remaja yang ada di RW 3 Desa Sukatani Kecamatan Pacet, seperti masalah percintaan, masalah dengan orang tua, masalah antar pertemanan dan yang sering dijadikan konselor pada PIK Remaja OpeRa adalah Santi, Nita dan Ujang Nurul Huda yang kebetulan diangkat menjadi pengurus PIK Remaja dan konselor sebaya. Hal ini dikarenakan mereka bertiga memiliki tingkat pendidikan yang relatif tinggi, aktif diberbagai kegiatan baik di Barukupa maupun di luar wilayah Kampung Barukupa. Dan karakteristik ketiga orang tersebut ramah, merupakan pendengar yang baik, mampu menyimpan rahasia serta mampu memberikan solusi yang bijak. Namun tingkat pendidikan serta usia mereka yang relatif dewasa kurang bisa meraih remaja dengan rentan usia kisaran 10-15 tahun atau usia SLTP. Cenderung kurang terbuka dengan konselor Santi dikarenakan usia yang terpaut relatif jauh akan tetapi lebih terbuka kepada Ujang Nurul Huda dikarenakan Ujang Nurul Huda merupakan guru di MTs tempat mereka sekolah yang lebih banyak berinteraksi dengan remaja tanggung. 
Jurnal Komunikasi Universitas Garut: Hasil Pemikiran dan Penelitian

Vol. 7, No. 1, April 2021

Halaman 591-605

Pola Bahasa Komunikasi Verbal dan Nonverbal pada Komunikasi Peer group Remaja dalam Program Kampung Kuba

oleh $\begin{gathered}\text { Komunikasi verbal yang digunakan } \\ \text { remaja Barukupa dalam }\end{gathered}$ berkomunikasi adalah bahasa daerah Sunda dan bahasa nasional yaitu Bahasa Indonesia namun yang lebih dominan adalah bahasa daerah. Yang kedua konotatif mengandung pengertian emosional atau evaluatif, oleh karena itu dapat menimbulkan interpretasi yang berbeda pada komunikan, khususnya pada komunikasi lisan seperti gaya bicara, tekanan nada, volume suara, logat dan sebagainya. Dikarena lingkungan Barukupa merupakan daerah pengunungan volume suara para remaja relatif tinggi namun memiliki logat bicara yang khas yaitu logat sunda. Pada saat melakukan observasi dan tahapan wawancara remaja Barukupa lebih cenderung pemalu, dan sulit terbuka terhadap orang baru, dengan berbagai pendekatan hanya beberapa remaja yang mau bergabung hal ini yang menjadi salah satu penghambat pengembangan PIK Remaja dimana hanya konselor sebaya saja yang mampu mendekati remaja dan fasilitator pihak luar mengalami sedikit kesulitan. Penanggungjawab kegiatan PIM Remaja aktif berkonsultasi dengan pembina tingkat Kecamatan dalam penyaluran ide atau gagasan remaja namun mengalami berbagai macam hambatan terutama dalam penyesuaian waktu pembinaan.

Lambang Nirverbal adalah lambang yang digunakan dalam komunikasi yang bukan bahasa misalnya kial, isyarat dengan anggota tubuh maupun gambar. Salah satu nirverbal yang pernah digunakan adalah isyarat tubuh seperti gambar di bawah ini yang memiliki arti "katakan tidak untuk pernikahan dini, katakan tidak untuk seks pra nikah dan katakan tidak untuk Napza. Untuk isyarat ini hanya sebagian remaja saja yang memahami maknanya, sedangkan lambang Pik Remaja sendiri belum memiliki lambang atau logo tersendiri. Sedangkan bahasa tubuh yang sering ditemui adalah sebagian remaja yang sering menutup sebagian wajah atau menundukkan kepala apabila diajak komunikasi oleh orang luar namun antar remaja mereka bersikap biasa.

\section{Kendala Komunikasi Peer group Remaja di Kampung KB Barukupa}

Adapun beberapa kendala yang dialami dalam pendekatan peer group remaja di Kampung KB Barukupa, diantaranya:

a. Pemahaman remaja mengenai program-program PIK Remaja masih kurang hal ini berdasarkan hasil wawancara dan observasi lapangan sebagian remaja bahkan belum mengetahui apa itu PIK $\mathrm{R}$ dan programnya.

b. Pihak penanggungjawab kegiatan PIK Remaja sudah beberapa kali mengajukan pembinaan kepada pihak DPPKBP3A selaku penanggungjawab program sampai saat ini belum ada respon.

c. Setelah dilakukan konfirmasi kepada pihak DPPKBP3A mengenai kegiatan pembinaan, pihak pembina tingkat desa yaitu Ibu Ani Kusdini, S.Sos menyatakan dan mengiyakan mengenai keinginan remaja Barukupa untuk menyelenggarakan kegiatan pembinaan, namun hal ini belum bisa terealisasi dikarenakan personil pembina kelompok kegiatan 
Kecamatan Pacet yang kurang dengan wilayah kerja terdiri dari 7 Desa binaan hanya memiliki personil 3 pembina kegiatan dengan jumlah Kampung KB yang dibentuk 5 wilayah dengan kelompok kegiatan masingmasing wilayah memiliki 5 kelompok kegiatan yaitu Bina Keluarga Balita (BKB), Bina Keluarga Remaja (BKR), Bina Keluarga Lansia (BKL), Usaha Peningkatan Pendapatan Keluarga Sejahtera (UPPKS0 dan PIK Remaja.

d. Kendala yang dihadapi setiap akan melakukan pembinaan penyesuaian waktu antara pembina dan yang akan dibina, terutama PIK Remaja cenderung harus memanfaatkan waktu liburan sekolah karena sistem pendidikan kita yang full day sehingga hampir tidak ada waktu untuk melaksanakan pembinaan pada waktu jam kerja.

e. Tidak adanya dukungan dana dan adanya ketidaktranparannya mengenai dana pembinaan kegiatan PIK Remaja yang bersumber dari APBN.

\section{Kesimpulan}

Interaksi komunikasi teman sebaya memberikan pengaruh yang cukup kuat dalam pembentukan karakter, pola pikir serta pengambilan keputusan remaja, karena teman sebaya merasa sama-sama memiliki kehidupan dan nasib yang relatif sama terutama pada rentan usia remaja antara 10 hingga 15 tahun. Untuk mensiasati pengaruh teman sebaya yang mengarah ke pergaulan negatif dilibatkan agent of change yang dikenal baik dan disegani kelompok remaja tersebut sehingga memberikan rasa nyaman kepada mereka untuk membangun hubungan komunikasi yang terbuka sehingga memudahkan remaja tanggung untuk diarahkan pada pergaulan yang lebih sehat.

Selain program PIK Remaja, para remaja yang tergabung dalam kegiatan program PIK Remaja memiliki kegiatankegiatan yang hampir mirip dengan program PIK Remaja berjalan tidak berdasarkan organisasi resmi PIK Remaja. Kegiatan berjalan berdasarkan rasa ingin pengakuan keberadaan remaja oleh masyarakat serta adanya keterkaitan kelompok lainnya yang peduli akan perkembangan pergaulan remaja di Barukupa, baik itu dibidang keagamaan, olahraga, maupun akses untuk mendapatkan keterampilan yang lebih baik. Kegiatan-kegiatan tersebut menjadi stimulan bagi remaja yang tergabung dalam PIK R yang malah lebih aktif di luar program PIK Remaja. Selain itu, akses internet memudahkan mereka untuk mendapatkan informasi melalui media sosial mengenai pergaulan bebas dan perilaku seks bebas yang lebih mendistorsi pengetahuan mereka mengenai bahayanya perilaku seks bebas, dan resiko pernikahan usia dini.

Sementara itu, yang menjadi saran dari penelitian ini adalah keberadaan konselor sebaya diharapkan lebih ditingkatkan lagi jumlahnya melalui pembentukan agen-agen perubahan (agents of change) yang berasal dari lingkungan desa Sukatani untuk memudahkan pendekatan kepada remaja Barukupa yang lebih cenderung pemalu, dan sulit terbuka terhadap orang baru, terutama yang usianya terpaut jauh dari mereka. Sehingga kegiatan program PIK Remaja dapat lebih mudah diterima dan mendapat dukungan remaja sekitarnya melalui pola komunikasi peer group. Saran lainnya adalah perlu adanya pengkayaan 
Jurnal Komunikasi Universitas Garut: Hasil Pemikiran dan Penelitian

Vol. 7, No. 1, April 2021

Halaman 591-605

dan penguatan konten program Kampung KB PIK Remaja yang disesuaikan dengan kebutuhan dan ketertarikan remaja terhadap up date informasi yang bisa mereka dapatkan melalui media sosial. Saran terakhir adalah perlu adanya pengembangan program Kampung KB PIK Remaja melalui pemanfaatan jejaring media sosial untuk menghindari distorsi informasi mengenai kesehatan reproduksi dan pergaulan seks bebas, serta memperluas media informasi program PIK Remaja dengan melibatkan remaja di desa Sukatani melalui pendekatan peer group sehingga diharapkan dapat menumbuhkan dampak positif terhadap kebutuhan pengakuan eksistensi remaja desa Sukatani dari masyarakat luas.

\section{Daftar Pustaka}

Agustin, Sari Monik. (2014). Komunikasi Peer-Group tentang Konsep Kekerasan dan Bullying (Studi Groupthink Theory \& Sosialisasi Anti Kekerasan dan Bullying pada Siswa SMA Negeri 70, BulunganJakarta). Jurnal AL-AZHAR INDONESIA SERI PRANATA SOSIAL, 2 (3).

Ardianto, Elvinaro. (2011). Metodologi Penelitian untuk Public Relation Kuantitatif dan Kualitatif. Bandung: Simbiosa Rekatama Media.

Arikunto. (2012). Manajemen Penelitian. Jakarta: Rineka Cipta.

BKKBN. (2014). Pedoman Pengelolaan Pusat Informasi dan Konseling Remaja dan Mahasiswa (PIK R/M). Jakarta: Direktorat Bina Ketahanan Remaja.

BKKBN. (2018). Pengelolaan Kampung
KB. Bandung: BKKBN Provinsi Jawa Barat.

Bungin, Burhan. (2003). Metode Penelitian

Kualitatif. Jakarta: PT Raja Grafindo Persada.

Direktorat Bina Ketahanan Remaja. (2014). Pedoman Pusat Informasi dan Konseling Remaja dan Mahasiswa. Jakarta: Badan Kependudukan dan Keluarga Berencana Nasional.

Moleong, Lexy J. (2006). Metodologi Penelitian Kualitatif Edisi Revisi. Bandung: PT Remaja Rosdakarya Offset.

Daymon, Christine., dan Immy Holloway. (2008). Metode-metode Riset Kualitatif: dalam Public Relations dan Marketing Communications. Yogyakarta: Penerbit Bentang.

Mulyana, Deddy. (2011). Ilmu Komunikasi: Suatu Pengantar. Bandung: PT Remaja Rosdakarya.

Pradanari, Wening Jiwandaru. (2014). Hubungan antara Parental Discipline dan Intensitas Komunikasi Peer group dengan Minat Belajar Anak. Skripsi. Semarang: Jurusan Fakultas Ilmu Sosial dan Ilmu Politik Universitas Diponegoro.

Putri, Eleonora Lintang Hapsoro. (2017). Hubungan Terpaan Iklan Rokok di Televisi dan Intensitas Komunikasi Peer group dengan Minat Merokok Remaja Perempuan. Skripsi. Semarang: Jurusan Fakultas Ilmu Sosial dan Ilmu Politik Universitas Diponegoro.

Rahmayantie, Erieke Nindha. (2016). Memahami Komunikasi Keluarga dan Peer group dalam Pengambilan 
Jurnal Komunikasi Universitas Garut: Hasil Pemikiran dan Penelitian

Vol. 7, No. 1, April 2021

Halaman 591-605

Keputusan Berhijab. Skripsi.

Semarang: Jurusan Fakultas Ilmu

Sosial dan Ilmu Politik Universitas

Diponegoro.

Romandoni, Ikhvan, \& Suryawan, Wawan

Ardiyan. (2017). Desain Ruang

Relaksasi untuk Stres di Perkotaan

dengan penerapan Biophilic

Design. Jurnal Sains dan Seni

Pomits. 6 (2). G104-G108.

Septiyuni, Dara Agnis. (2014). Pengaruh

Kelompok Teman Sebaya Peer group terhadap Perilaku Bulliying di Sekolah: Studi terhadap Siswa SMA Negeri di Kota Bandung. Skripsi. Bandung: Universitas Pendidikan Indonesia.

Simabur, Lisda Ariani. (2014).

Komunikasi Pemasaran Festival

Legu Gam Moloku Kie Raha.

Tesis. Program Pascasarjana

Universitas Islam Bandung.

UMY, B. (2016, Februari 28). bhp@umy.ac.id. 